\title{
9. POST-TECTONIC SUBSIDENCE OF THE CÔTE D'IVOIRE-GHANA MARGINAL RIDGE: INSIGHTS FROM FMS DATA ${ }^{1}$
}

\author{
Christophe Basile, ${ }^{2}$ Jean Michel Ginet, ${ }^{2}$ and Philippe Pezard ${ }^{3}$
}

\begin{abstract}
During Ocean Drilling Program (ODP) Leg 159, Sites 959 and 960 were drilled on the northern slope and near the top of the Côte d'Ivoire-Ghana Marginal Ridge, at the intersection of the divergent Ivorian Basin and a transform margin. On seismic lines, this ridge appears as an acoustic basement tilted northward. It comprises Albian siliciclastic synrift sediments, unconformably overlain by Turonian to Santonian carbonate debris flows (postrift but syntransform sediments). These sediments are overlapped along the northern ridge slope by Upper Cretaceous-Paleocene claystones and Paleocene-Eocene porcellanite.

The Formation MicroScanner (FMS) logging tool has recorded images of the borehole wall between 546 meters below seafloor (mbsf) (porcellanite) and 924 mbsf (claystones) in Hole 959D, and between 331 and 351 mbsf (grainstones) in Hole 960C. From these images, strata and fault attitudes have been systematically measured (1771 beds and 694 faults measured in Hole 959D, and 257 beds and 13 faults in Hole 960C) to study the progressive tilting of the ridge and coeval deformation.

In Hole 959D, the average dip of the bedding increases with depth, from $7^{\circ}$ at $550 \mathrm{mbsf}$ to $16^{\circ}$ at $920 \mathrm{mbsf}$. The mean azimuth remains constant, around $320^{\circ} \mathrm{N}$. These changes indicate a progressive northwestward tilt of the marginal ridge from the Upper Cretaceous to the Eocene. However, both dip and azimuth measurements exhibit important variations that cannot be ascribed to measurement resolution. In Hole 960C, the attitudes of bedding exhibit the same variations, with an average azimuth around $20^{\circ}$.

Changes in dip and azimuth values can be correlated at a decimeter-to-meter scale and indicate progressive rotations about horizontal axes. At both Sites 959 and 960, direct observations on cores and strong correlation between rotation axis and fault strikes indicate that many rotations are related to tilting along low-dipping and gravity-driven normal faults. Sedimentary structures such as cross lamination or progradation can also explain rotations of successive beddings, especially at Site 960 where grainflows were observed. Averaging the dip and azimuth over a large interval $(20 \mathrm{~m})$ emphasizes the occurrence of several wavelengths in the depth domain for the progressive tilts.

Finally, the northern slope of the Marginal Ridge results from a combination of tilting around several horizontal rotation axes. The rotations are mainly controlled by the contemporaneous thermal subsidence of the transform and divergent margins. Moreover, some faults and rotation axis directions can be associated with paleo-stresses, especially in the syntransform limestones of Hole 960C.
\end{abstract}

\section{INTRODUCTION}

Located on the northern edge of the Gulf of Guinea, the Côte d'Ivoire-Ghana Transform Margin is a narrow and elongated continental margin lined up with the Romanche Fracture Zone (Fig. 1). This transform margin is characterized by a sharp contact between continental and oceanic lithospheres. Between the shelf and the abyssal plain, the continental slope is only 20 to $30 \mathrm{~km}$ wide (Basile et al., 1996), and at depth, the transition between the continental Moho (21 $\mathrm{km}$ deep) and the oceanic one (11 km deep) is less than $10 \mathrm{~km}$ wide (Sage et al., 1997).

In the western termination of the transform margin, the most prominent feature is a marginal ridge located between a thinned continental crust northward (the Deep Ivorian Basin), and the oceanic crust southward. In the present-day bathymetry, the Marginal Ridge is a kind of plateau at $2000 \mathrm{~m}$ depth. Seismic sections (e.g., Fig. 2) show that this ridge has the shape of a northward-tilted crustal block. The northern slope of this ridge is entirely covered by a sedimentary sequence partly contemporaneous with the tilting. Basile et al. (1993) have proposed four geodynamic stages where the Marginal Ridge is progressively built:

1. The first stage (early rifting of the Deep Ivorian Basin) leads to shearing in the ridge area. At that stage, a hypothetical slight uplift of

${ }^{1}$ Mascle, J., Lohmann, G.P., and Moullade, M. (Eds.), 1998. Proc. ODP, Sci. Results, 159: College Station, TX (Ocean Drilling Program).

${ }^{2}$ Laboratoire de Géodynamique des Chaînes Alpines, CNRS-UPRES-A 5025, 15 rue Gignoux, 38031 Grenoble Cedex, France. cbasile@ujf-grenoble.fr

${ }^{3}$ Laboratoire de Mesures en Forage, Institut Méditerranéen de Technologie, 13451 Marseille Cedex 20, France the ridge is strictly related to differential tectonic subsidence (i.e., faster crustal thinning in the Ivorian Basin than at its southern border).

2. At the end of the rifting, a second stage is correlated with the development of an intracontinental fault at the emplacement of the Marginal Ridge. At that time, tectonic transpression is the more likely mechanism that can uplift the Ridge (Mascle and Blarez, 1987). However, differential thermal subsidence (faster cooling of the Ivorian Basin than the Ridge) could be a second mechanism.

3. Final continental parting between African and South American plates brings the continental transform margin into contact with the oceanic lithosphere in the Gulf of Guinea. At that stage, the transform margin is tectonically active and experiences a progressive heating by the adjacent oceanic lithosphere. The heating and subsequent ther-

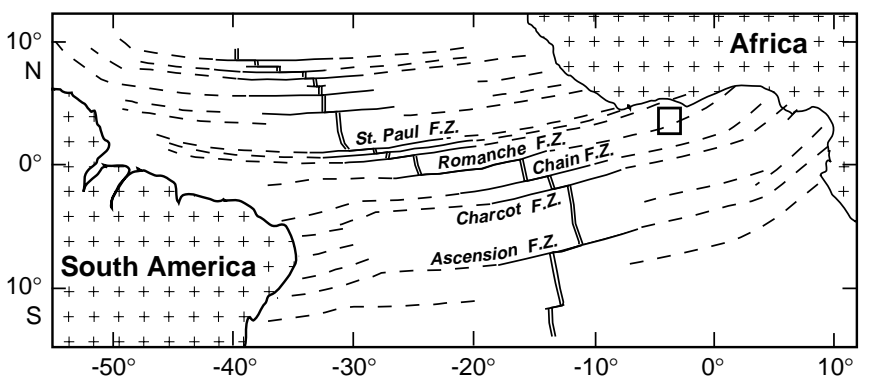

Figure 1. Fracture zones in the equatorial Atlantic and associated continental margins (modified from Gorini, 1977). The box locates the studied area. F.Z. $=$ fracture zone. 


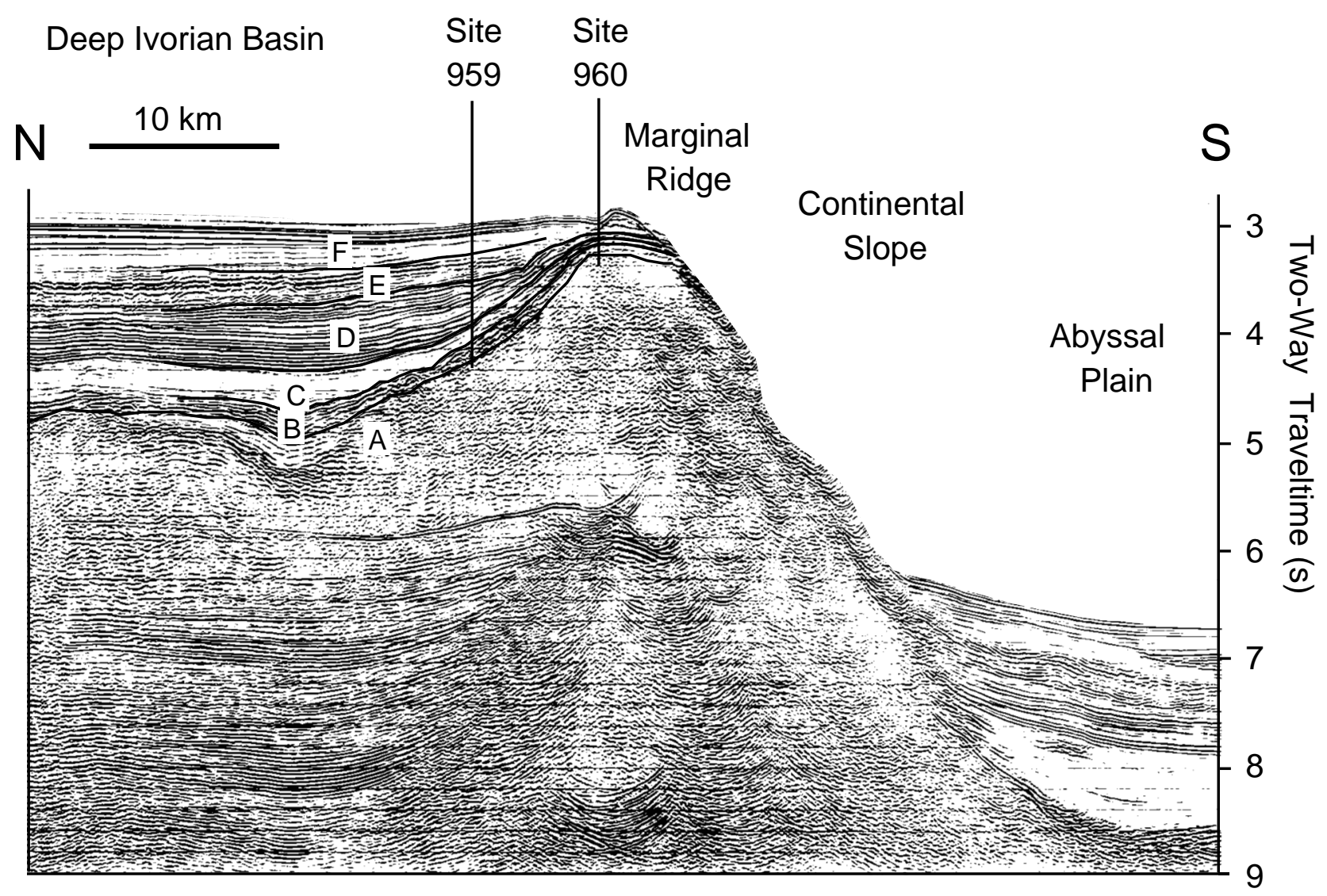

Figure 2. MCS Line MT02 across the Deep Ivorian Basin and the Marginal Ridge of the Côte d'Ivoire-Ghana. The section illustrates the asymmetry of the ridge and the progressive tilting of the sedimentary layers pinching out against the northern slope of the Marginal Ridge. A through $\mathrm{F}=$ seismic stratigraphic units (see text for details).

mal uplift of the Marginal Ridge increases with time as the oceanic crust is younger and closer to the spreading axis.

4. Finally, when the spreading axis passes south of the Marginal Ridge, the continental margin becomes tectonically inactive and starts to thermally subside, probably at a slower rate than that of the adjacent rifted Ivorian Basin.

One of the principal objectives of Ocean Drilling Program (ODP) Leg 159 was to investigate the mechanisms of formation of the Marginal Ridge, and particularly the uplift and subsidence history. Sites 959 through 962, drilled during this leg, define two sections of the transform margin, one perpendicular to the Marginal Ridge (Sites 959 and 960; Fig. 2), another along the strike of the Marginal Ridge (Sites 960 through 962).

Different tools can be used to estimate the vertical motions that occurred in the margin. Variations of subsidence and uplift through time can be evaluated by reconstruction of the sedimentary environments at each site, and variations through space can be evaluated by comparing both sites. As differential subsidence or uplift between sites induces tilting, spacial variations of subsidence can also be evaluated by the changes in dip and strike of the sedimentary beds. Those structural measurements can be done in situ using the Formation MicroScanner (FMS) logging tool, which produces high-resolution micro-resistivity images of the borehole wall.

In this paper, we study the FMS data recorded in Holes 959D and 960C. Unfortunately, Site 961 was not logged because of hole instability, and FMS data cannot be interpreted at all at Site 962 (Hole 962D) because of poor borehole conditions (bridges and numerous washouts). Again because of poor borehole conditions, only $30 \mathrm{~m}$
(323-351 meters below seafloor [mbsf]) from Hole 960C, located at the top of the Marginal Ridge, could be used in this study. Hole 959D is located only three miles north of Hole 960C, on the northern slope of the Marginal Ridge and is the main hole studied in this paper. In Hole 959D, FMS data were recorded in the interval 546.9 to 936.8 mbsf (with a repeat pass between 655.1 and $932 \mathrm{mbsf}$ ).

\section{SEDIMENTARY SEQUENCES AT SITES 959 AND 960: SEISMIC AND LITHOLOGIC DATA}

A first step in the investigation of uplift-subsidence history is the comparison between the sedimentary sequences, depths, thicknesses, and sedimentary environments at Sites 959 and 960 . From seismic reflection data (Basile et al., 1996), the sedimentary sequence seems to be similar at depth (seismic Units A and B) at Sites 959 and 960 (Fig. 2 ). The thickness of Unit B changes slightly, and the whole unit is tilted toward the north-northwest. A similar pattern is deduced from the cores recovered at Sites 959 and 960 (Mascle, Lohmann, Clift, et al., 1996). During Early Cretaceous (Albian?) times (Stage 2), a siliciclastic sedimentary sequence (seismic Unit A) was deposited in similar lacustrine environments at Sites 959 and 960, probably inside a basin bounded by two intracontinental transform faults. An erosional and angular unconformity overlies those sediments and is covered by middle (Site 959) to lower (Site 960) Turonian carbonates. This unconformity is the base of seismic Unit B (Stage 3, continent-ocean transform) and marks the beginning of the deepening of the ridge slope by reference to the ridge crest. At that time, periplatform depos- 
its, debris, and grain flows came from a shallow shelf setting near Site 960 into an adjacent basin (Site 959 and northward). Siliciclastic grains coming from the south uplifted regions of this ridge or other continental fragments also indicate eroded reliefs and vertical motions.

After the late Santonian, the end of the carbonate sedimentation is associated with a regional deepening of the basin and ridge, and a marked difference between sedimentary environments at Sites 959 and 960 appears. This change of sedimentation fits with seismic Units $\mathrm{C}$ and $\mathrm{D}$, which overlap the northern ridge slope and become considerably thinner toward the top of the Marginal Ridge (Fig. 2). Their north-northwest tilt progressively decreases upward. Hardgrounds and condensed Coniacian to Santonian sedimentary sequences are overlain by $209 \mathrm{~m}$ of Upper Cretaceous to Paleocene black claystones at Site 959, while no sediment was deposited at Site 960 in the same time interval. Upper Paleocene chalk is again located only at Site 959 . Beginning in the early Eocene, biosiliceous sedimentation (porcellanite, chert, and diatomite) influenced sediment deposition at all sites, but with very important differences in thicknesses between Sites $959(604 \mathrm{~m})$ and $960(75 \mathrm{~m})$. Neogene sediments (seismic Units E and F) are pelagic and hemipelagic oozes and chalk. They are similar at both Sites 959 and 960, but again become thicker at Site 959.

So the northward thickening of the sedimentary sequence appears in the late Santonian, when the sedimentation loses the clastic input and becomes only pelagic and hemipelagic. The disappearance of clastic sediments excludes a sedimentary origin (such as progradation) for the change of thickness of the sedimentary layers; this change is clearly related to a change in sedimentation depths. The progressive deepening of the Ivorian Basin with respect to the Marginal Ridge induced a contemporaneous tilting of the sedimentary layers.

This tilting can be estimated by comparing the depths of some sedimentary interfaces in Holes 959D and 960C (Table 1). The dips given in Table 1 are apparent because the sedimentary bedding is not dipping north like the strike between Holes 959D and 960C), but northnorthwest. The true dips are slightly steeper than those shown in Table 1 . The apparent dips decrease from the deeper units $\left(10^{\circ}-11^{\circ}\right.$ at the Albian-Turonian unconformity, top Unit V) to the shallower ones- $8^{\circ}$ at the base of Eocene biosiliceous sediments, $4^{\circ}$ at the base of Neogene sediments, and only $2^{\circ}$ in the Miocene. This progressive tilting observed at a kilometer scale has also been studied at a centimeter scale using FMS logging in the same holes.

At Site 959, the interval (930-540 mbsf) logged by the FMS tool and studied in this paper is limited to the seismic Units C and D. The lower part of this interval is in the Upper Cretaceous to Paleocene black claystones (930-825 mbsf), and the upper part covers the upper Paleocene chalk (limited to the $825-810$ mbsf interval) and the Eocene porcellanite ( $810-540 \mathrm{mbsf})$. In the porcellanite, biosiliceous, and pyrite-rich sediments are interbedded with pelagic calcareous sediments; the contacts between beds are generally gradational because of moderate bioturbation by Zoophycos, Chondrites, and $\mathrm{Pl}$ - anolites, and the bedding often appears in cores as flattened burrows (Mascle, Lohmann, Clift, et al., 1996).

At Site 960, FMS data have been interpreted only in the interval 323-351 mbsf. This interval is inside seismic Unit B, which consists of Turonian to Coniacian limestones.

\section{FMS TOOL}

The Formation MicroScanner (FMS) logging tool has been developed by Schlumberger for ODP purposes. This tool consists of four orthogonal pads pressed against the borehole wall. Each pad produces high-resolution micro-resistivity images of the wall (Fig. 3) (Mascle, Lohmann, Clift, et al., 1996; Serra, 1989). Processing converts the resistivity measurements into spatially oriented images using data recorded by an inclination tool (GPIT) deployed together with the FMS. Any plane not perpendicular to the borehole axis that intersects the borehole wall is represented as a sine wave when the borehole wall is unrolled (Serra, 1989). The apparent azimuth (with respect to the borehole orientation) of this plane is the azimuth of the deepest point of the sine wave, whereas the apparent dip is computed from the amplitude of the sine wave and the hole diameter. All measurements presented in this paper are corrected for the deviation of the hole (measured by the GPIT) and are true dips and azimuths, relative to horizontal and north.

On FMS images, the bedding is defined by a sharp contrast between layers characterized by different resistivities (Fig. 3). Conductive layers appear dark; resistive layers appear clear. For example, at Site 959, the upper part of the logged interval consists of biosiliceous, pyrite-rich, and conductive sediments interbedded with calcareous sediments, which are more resistive. When the FMS image is displayed, it is possible to modify the relationship between resistivity and color. This adjustment increases the measurement resolution and the number of beds that can be observed on FMS images. Faults are defined as conductive planes (black lines on FMS images) crossing the bedding. Highly deformed fault zones, however, are quite hard to analyze because image coverage is restricted to about $22 \%$ of the borehole wall.

\section{STRUCTURAL MEASUREMENTS}

In Hole 959D, structural measurements were performed by two of the authors, C. Basile in all of Hole 960C and in the intervals 546721.27 mbsf and 749.36-924 mbsf of Hole 959D on pass 1 and J.M. Ginet in Hole 959D between 709.99 and 776.88 mbsf on pass 2. We used Fracview software developed by Schlumberger to identify and measure the attitudes (dip and dip direction = azimuth) of beds and faults. Measurements were always taken using the same method for sedimentary beddings by plotting at least three points on the measured plane and computing the sine that provides the best fit for those three points. For fault measurements, C. Basile used the same method

Table 1. Depths and apparent dips of some sedimentary interfaces in and between Holes 959D and 960C.*

\begin{tabular}{lcccccc}
\hline & \multicolumn{2}{c}{ Depth (mbsf) } & \multicolumn{2}{c}{ Depth (m) below surface } & & $\begin{array}{c}\text { Apparent slope } \\
\left({ }^{\circ}\right)\end{array}$ \\
\cline { 2 - 3 } Interface & Hole 959D & Hole 960A & & Hole 959D & Hole 960A & between Holes 960C and 959D \\
\hline T IIA & 207.6 & 101.0 & & 2298.3 & 2149.3 & 1.8 \\
T IIB & 427.3 & 136.2 & & 2518.0 & 2184.5 & 4.1 \\
T III & 810.0 & 164.8 & & 2900.7 & 2213.1 & 8.3 \\
T IVA & 1043.3 & 176.0 & & 3134.0 & 2224.3 & 9.6 \\
T V & 1081.7 & 330.0 & & 3172.4 & 2378.3 & 9.3 \\
\hline
\end{tabular}

Notes: * = Mascle, Lohmann, Clift, et al. (1996). Interface = lithostratigraphic units, T = top. The top of lithostratigraphic Univ V (Lower Cretaceous) fits with the top of seismic Unit A. The top of lithostratigraphic Unit IVA is upper Santonian in age, and fits with the top of seismic Unit B. The tops of Unit III and Subunits IIB and IIA are early Eocene, Neogene, and early Miocene in age, respectively (Mascle, Lohmann, Clift, et al., 1996). 


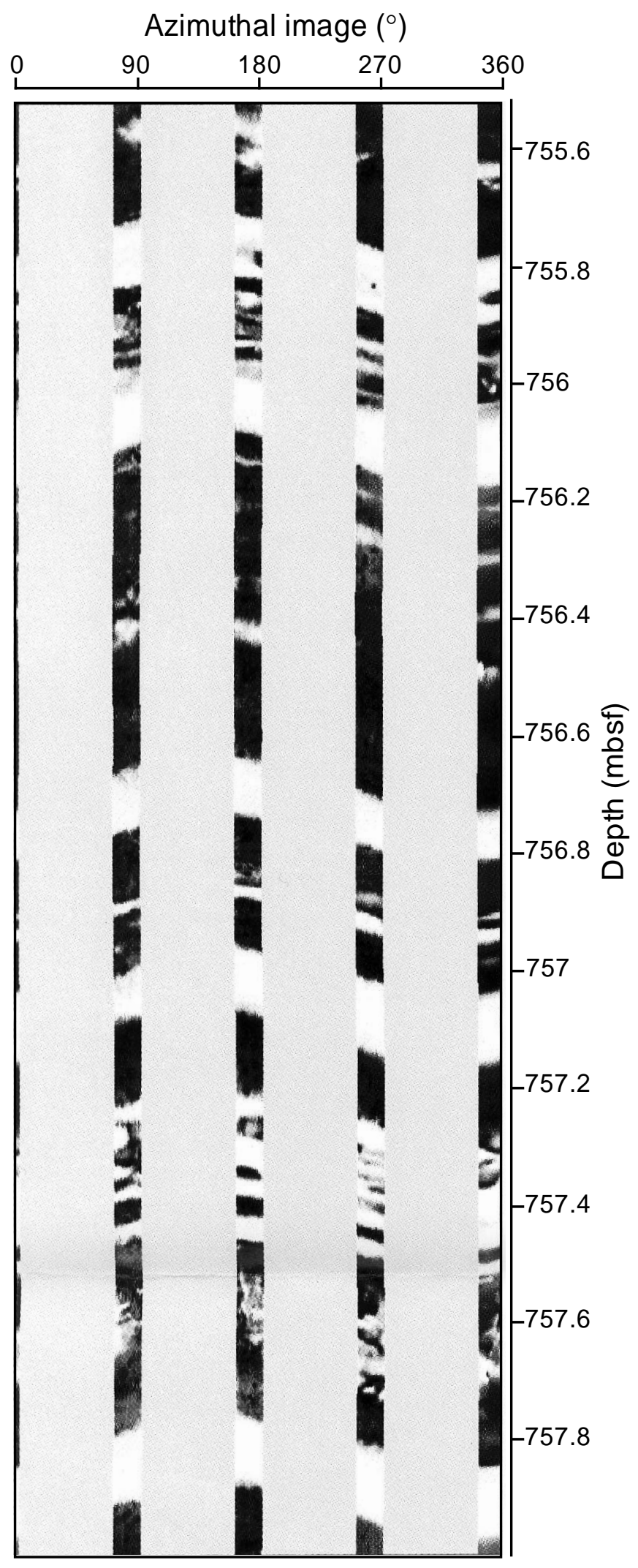

Figure 3. FMS azimuthal image from Hole 959D, 755.52-757.98 mbsf. The same image is interpreted in Figure 8. as for beds; J.M. Ginet used a tool that automatically searches the conductive anomalies (assumed to be fractures) located in the vicinity of the plotted points, and computes the sine which provides the best fit for those anomalies. Only fossil faults have been measured; breakout induced by drilling or in situ present stresses were not measured in this study.

The results are very similar in bedding attitudes in the two studies, although more varied in fault attitudes. The small discrepancies that can be observed (Fig. 4) are mainly caused by a different sampling and a small shift in depth between the two FMS passes. Both studies are combined in the following descriptions, and data are shown together (in Hole 959D, C. Basile's findings from 546 to 720.9, J.M. Ginet's from 720.9 to 749.3 , and C. Basile's again from 749.3 to 924 mbsf).

\section{Hole 959D}

Figure 5 gives the azimuths and dips of the 694 faults reported on FMS images in Hole 959D. There is no significant variation of fault attitude in the logged interval. All azimuths are observed at all depths, and dips vary between $15^{\circ}$ and $75^{\circ}$. However, detailed examination of dip repartition shows two main dips: $45^{\circ}-50^{\circ}$ and $60^{\circ}-65^{\circ}$. On a strike rose diagram, all directions are observed, but preferential strikes appear. The more obvious strike is $65^{\circ} \mathrm{N}$, which is at a regional scale the strike of the Marginal Ridge. Another important strike occurs at $35^{\circ} \mathrm{N}$; other significant strikes occur at $165^{\circ}, 115^{\circ}$, and $95^{\circ} \mathrm{N}$. On the dip direction rose diagram, the faults trending $35^{\circ}$ and $65^{\circ} \mathrm{N}$ are the only ones that are dipping mainly in one direction (northwest). On average, those sets of faults are steeper (dipping $60^{\circ}-70^{\circ}$ ) than the others (dipping $\left.45^{\circ}\right)$. All the other sets $\left(95^{\circ}, 115^{\circ}\right.$, and $\left.165^{\circ} \mathrm{N}\right)$ consist of conjugated faults with opposite dips.

To the extent possible, each sedimentary bedding has been measured. However, those measurements were not possible when the sediments did not display resistivity contrasts (i.e., no contrasts on FMS images) in fault zones that prevent any correlation of beds at borehole scale, as well as when the shape and size of the hole decreased the quality of FMS records. In the 378-m-long logged interval of Hole 959D, 1771 beddings have been reported (Fig. 6). The average distance between two measurements is $21 \mathrm{~cm}$, but for half of the measurements this distance is less than $6 \mathrm{~cm}$. The dips measured from FMS images are similar to the dips measured shipboard on cores (Mascle, Lohmann, Clift, et al., 1996) once the shipboard dips are corrected from the hole deviation.

As expected from the seismic data, the whole sedimentary sequence logged by FMS is tilted northwestward. The dips vary from $7^{\circ}$ at $550 \mathrm{mbsf}$ to $16^{\circ}$ at $950 \mathrm{mbsf}$, while the average azimuth stays almost constant near $320^{\circ} \mathrm{N}$. The northwestward tilt then occurs around a horizontal axis striking at $50^{\circ} \mathrm{N}$. As the Marginal Ridge and its northern slope strike at $65^{\circ} \mathrm{N}$ on average, the average tilt recorded by the sedimentary layers between the Upper Cretaceous (924 mbsf) and middle-upper Eocene (546 mbsf) is not parallel to the ridge axis. Moreover, both dips and azimuths exhibit very important variations around their average values ( $\pm 50^{\circ}$ for azimuths, $\pm 8^{\circ}$ for dips), and those variations often appear as organized oscillations (see, for example, variations of azimuths in Figure 4) rather than as random signals. Sudden changes in bed attitude also exist; for example, the average dip increases from $10^{\circ}$ to $25^{\circ}$ between 720 and $800 \mathrm{mbsf}$, and then suddenly falls to $15^{\circ}$ between 800 and 810 mbsf (Fig. 6).

To evaluate the influence of measurement errors on dip and azimuth variations, we have plotted a set of 11 beds several times in the interval 759.8-761 mbsf, and compared the different measurements (Fig. 7). There are no significant variations of depth measurements (standard deviation $=$ between 0 and $1 \mathrm{~cm}$ ). On most of the planes, standard deviations are less than $2^{\circ}$ (maximum $4^{\circ}$ ) for azimuth measurements, and less than $0.6^{\circ}$ (maximum $1.65^{\circ}$ ) for dip measure- 


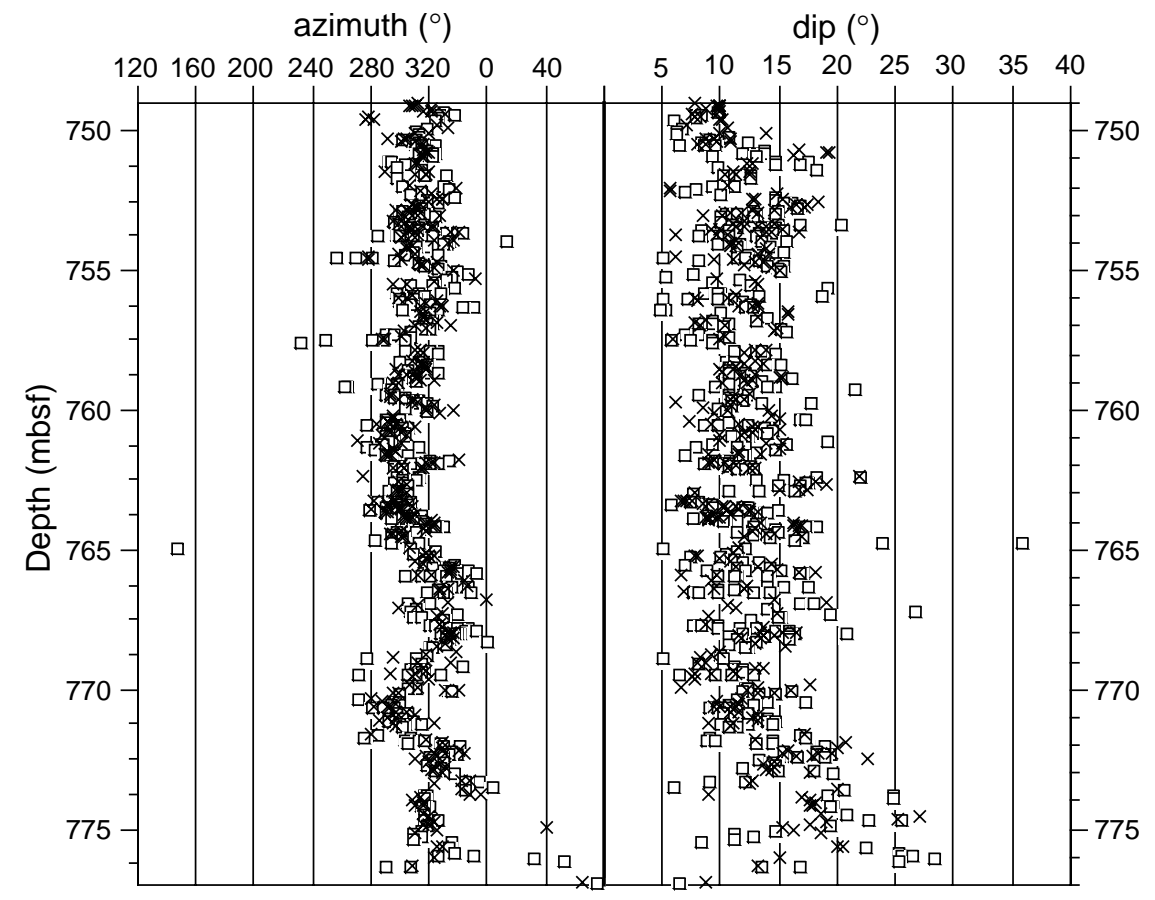

Figure 4. Bedding attitudes (azimuth and dip) measured by C. Basile (open squares) and J.M. Ginet (crosses) in the same interval (749-777 mbsf). ments. Those standard deviations are very small compared to the variations of azimuth (up to $30^{\circ}$ ) and dip (up to $7^{\circ}$ ) in this set of successive beds. This test confirms the measurement accuracy, and indicates that the variability of orientation of the sedimentary layers is not the result of data processing.

As both azimuth and dip of successive beds vary, one can try to spatially correlate those variations. Azimuth and dip often vary together, and it appears that those variations can be related to progressive rotations of the bedding, characterized by the orientation of the rotation axis and the way and amplitude of the rotation. One problem is to determine if the rotation has any geological reality, like in tilted blocks or progradation fans, or if it has only statistical means. In fact, one can always determine a rotation axis between two planes, but it is not always possible among three or more planes. So we decided to retain only the rotations determined by at least three successive planes progressively tilted in the same way (e.g., Fig. 8). Even with those restrictive constraints, almost all measured beds can be related to progressive rotations.

When the FMS images allow detailed analysis of the bedding without interruptions because of fault zones or poor quality of the borehole, only $2 \%-5 \%$ of the beds cannot be related to progressive rotations ( $0 \%$ in Fig. 8). This amount reaches $17 \%$ in beds that cannot be measured. To determine if this quantity can be reached randomly, a Monte Carlo test has been run on a set of 99 successive beds that are correlated at $96 \%$ to progressive rotations. Those data have been randomly mixed, and the new sequence of beds has been processed with the same rules (rotation determined by at least three successive planes progressively tilted in the same way) to find the rotation axis. Five tests have been performed, in which the 99 successive beds were correlated $66 \%-75 \%$ to progressive rotations. The difference with the $96 \%$ observed in the hole shows that the rotations are geologically significant and are not only the result of random distribution.

As almost all bedding measurements can be involved in progressive rotations, the thickness of the sets of successive bedding that define rotation axes ranges on a centimeter to decimeter scale (between 3 and $16 \mathrm{~cm}$ in Figure 8). Both increasing and decreasing downhole dips were observed. Some increasing and decreasing dips are consecutive, and are related to the same rotation axis (e.g., 756.88-757.04 mbsf, Fig. 8), but more commonly, they show a change in the rotation axis strike to as much as $90^{\circ}$ (e.g., 756.91-757.04 mbsf, Fig. 8). In Figure 8, the preferential trends of the rotation axes are $65^{\circ}$ and $90^{\circ} \mathrm{N}$, with a slight dip northwestward; strikes $145^{\circ}$ and $45^{\circ} \mathrm{N}$ also appear.

On the logged interval scale, rotation axes display the same feature as on a meter scale. They are striking in all directions (Fig. 9) and are slightly dipping northwestward. As the bedding is tilted in the same way, the rotation axes are horizontal by reference to the bedding. The dispersion of rotation axis strikes possibly represents a natural phenomenon like the dispersion of fault strikes or the variations of bed attitudes, but can also be the result of the imprecision of rotation axis computation. Four directions appear to be more significant (Fig. 9): $45^{\circ}, 65^{\circ}, 95^{\circ}$, and $145^{\circ} \mathrm{N}$.

At the logged interval scale (almost $400 \mathrm{~m}$ ), it is striking that the main directions of rotation axes $\left(45^{\circ}, 65^{\circ}\right.$, and $\left.95^{\circ} \mathrm{N}\right)$ are also the main orientations of the faults observed in the same interval (cf. Figs. $5,9)$. This is also true at other scales: the same preferential orientations of rotation axes are observed at the $10-\mathrm{m}$ scale as at the $400-\mathrm{m}$ scale, (cf. Figs. 9-10B or 8). Moreover, at the 10-m scale, the same directions are reported for both faults (Fig. 10A) and rotation axes (Fig. 10B). This systematic correlation probably indicates that faults and tilting are cogenetic.

As noted before, the variations of dip and azimuth can be observed on different scales: on a centimeter scale, that is between successive measurements (e.g., Figs. 7, 8), on a 5-m scale (e.g., on azimuth measurements in Fig. 4), or on a larger scale (Fig. 11). Figure 11 represents values of dip and azimuth averaged on a 20 -m interval (a low pass filtering has been applied to the data, and emphasizes the long-term variations). However, smoothing depends on the density of measurements and does not produce the same quality where there are few measurements $(600-700 \mathrm{mbsf})$ as where the measurements are numerous (700-800 mbsf).

Azimuth variations of smoothed data show a 40-m-long wavelength, and possibly a 300-m-long one (Fig. 11). Periodicity is less obvious for dip variations, but a $40-\mathrm{m}$ wavelength is also probable. However, the most striking feature is the increase of dip downhole between 720 and $800 \mathrm{mbsf}$, associated between 754 and $800 \mathrm{mbsf}$ to a progressive rotation around an axis striking $76^{\circ} \mathrm{N}$. This increase speeds up 
Figure 5. Azimuth and dip of faults in Hole 959D. Top: each measured fault is plotted in a depth vs. azimuth and dip diagram. Bottom: (from left to right) rose diagrams give the strike of fault planes (694 values, maximum 55 values), the dip direction (maximum 38 values) and dip value (maximum 79 values). For each histogram, the preferential strikes or dips are indicated; on the dip direction histogram, strike values (perpendicular to dip directions) are indicated.

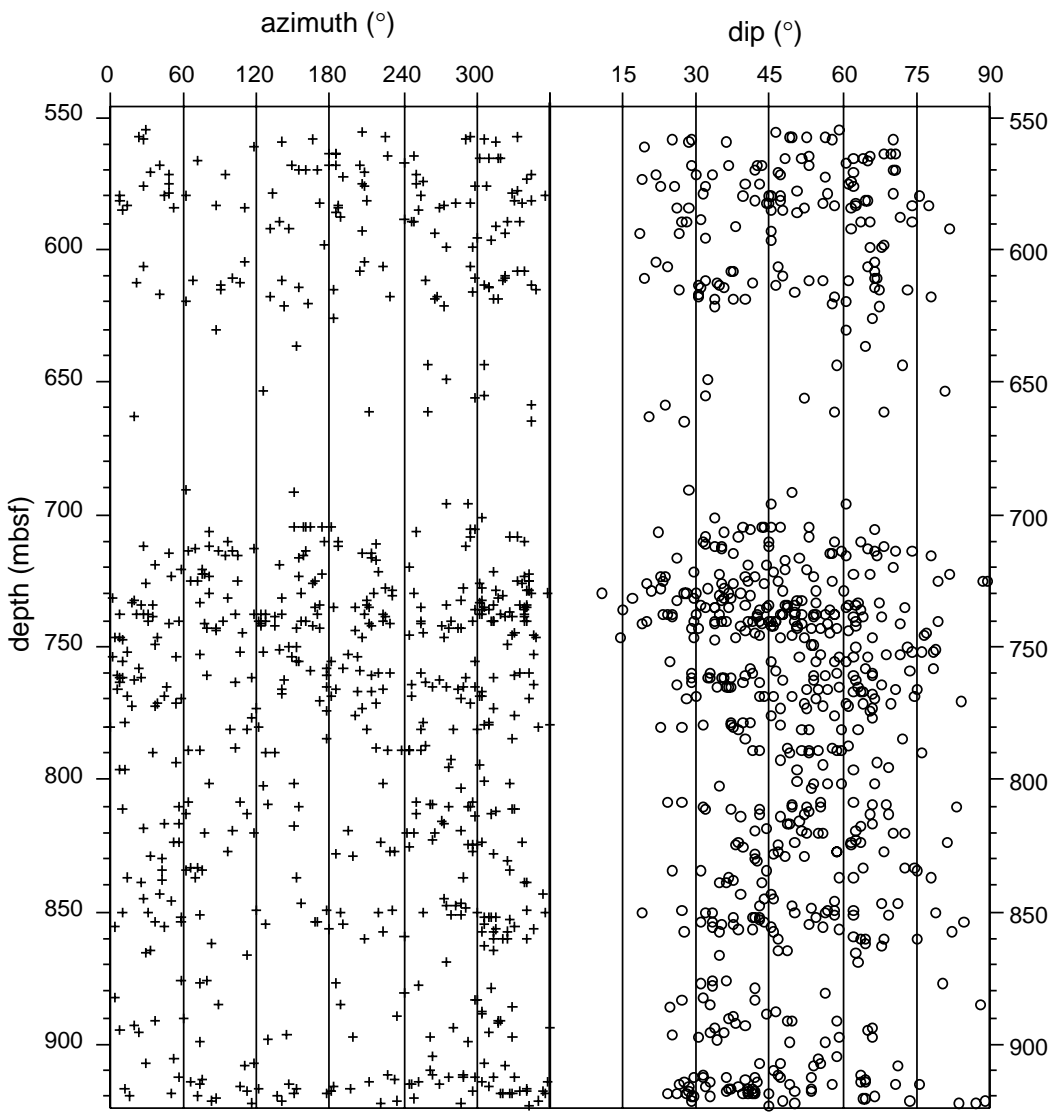

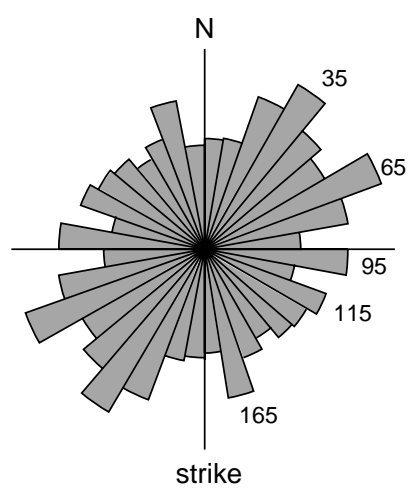

strike

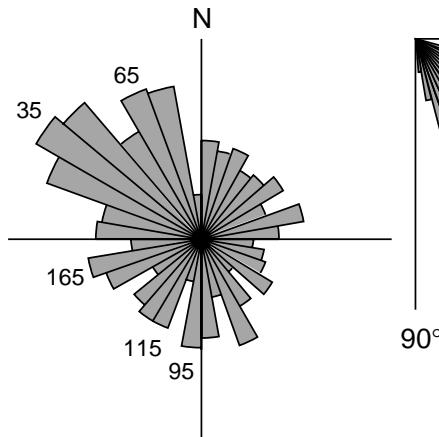

dip direction

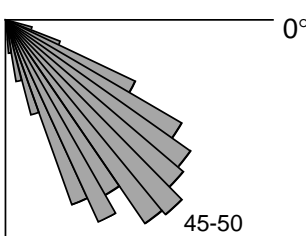

60-65 $90^{\circ}$

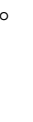

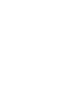

downhole and is suddenly stopped by a fall of the dips between 800 and $810 \mathrm{mbsf}$ (corresponding rotation axis striking $56^{\circ} \mathrm{N}$ ) and then an almost constant dip downhole ( $810-840 \mathrm{mbsf}$ ). This feature may be a tilted block, with a normal fault zone in the 800-810 mbsf interval where the beds are tilted by shearing, and a progressively tilted sedimentary infilling in the $750-800 \mathrm{mbsf}$ interval. This structure is also correlated with important changes occurring between 750 and 800 mbsf for index properties (velocity, density, and porosity), measured either on cores or in the hole (Mascle, Lohmann, Clift, et al., 1996).

Rotation axes retrieved from the smoothed data (Fig. 12) are preferably oriented following directions $90^{\circ}-105^{\circ} \mathrm{N}, 30^{\circ}-45^{\circ} \mathrm{N}$, and $150^{\circ}-165^{\circ} \mathrm{N}$. The preferential directions are very similar to those found on the sedimentary bed scale (few centimeter to decimeter scales), with the exception of the strike at $65^{\circ} \mathrm{N}$ (strike of the Marginal Ridge), which disappears on smoothed data.

\section{Hole 960C}

Because of the bad shape of the hole, only 13 faults have been reported in the small interval (323-351 mbsf) studied with the FMS tool in Hole $960 \mathrm{C}$. Those faults are preferably striking $130^{\circ}$ and $70^{\circ} \mathrm{N}$ (Fig. 13).

In Hole 960C, 257 sedimentary beds have been measured, mainly in the 323-351 mbsf interval (227 beds; Fig. 13). At the logged interval scale, the average dip is $15^{\circ}$, and there is no evident increase of dip downhole. On a smaller scale, such as in the 330-350 mbsf interval, the average dip increases downhole from $10^{\circ}$ to $20^{\circ}$. The average azimuth is approximately $20^{\circ} \mathrm{N}$, indicating an average north-northeast tilting. As in Hole 959D, the variations of dip and azimuth around their mean values are important. 


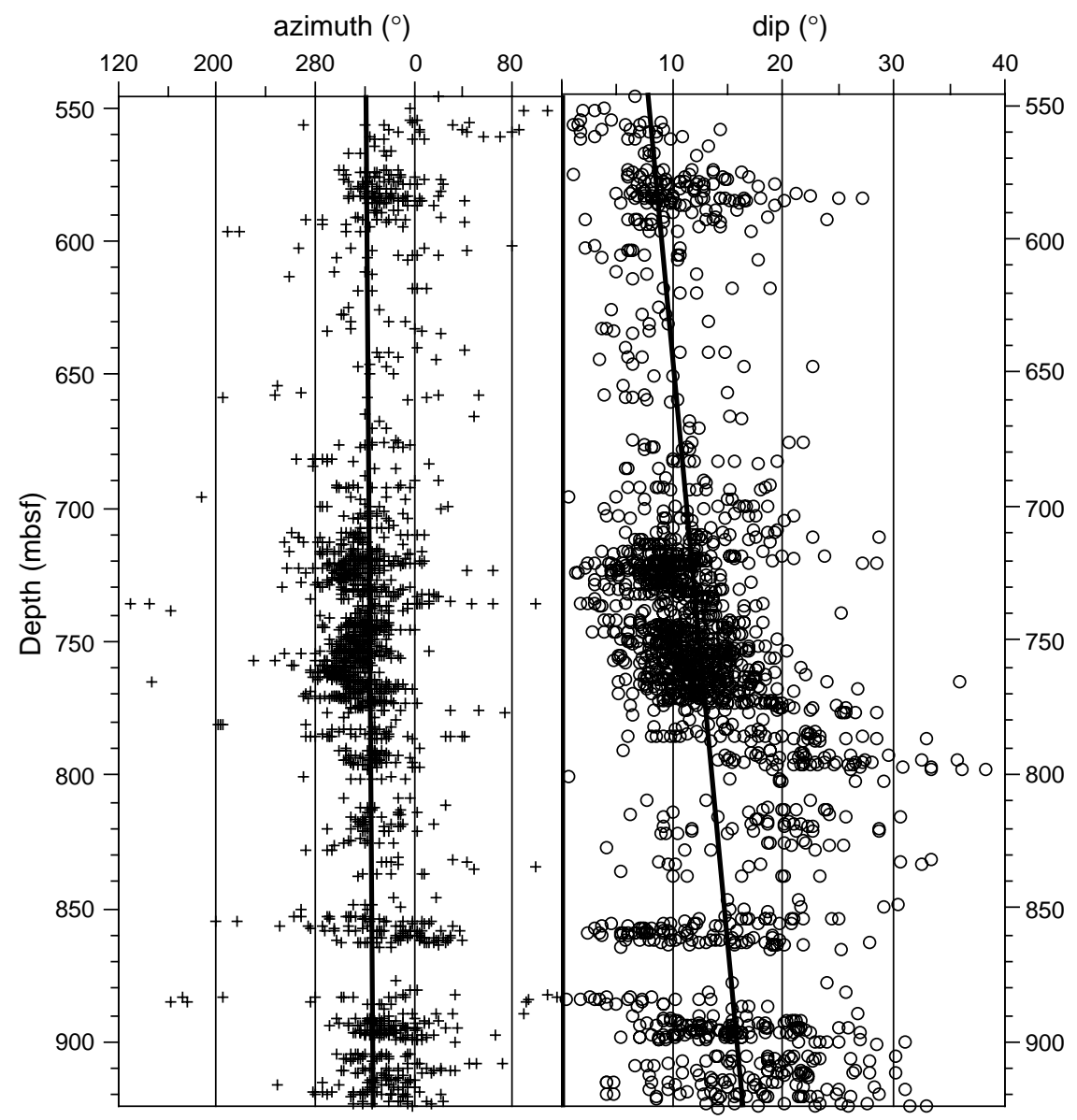

Figure 6. Azimuth and dip of sedimentary beds in Hole 959D. Each measured bed is plotted in a depth vs. azimuth and dip diagram. The thick lines are linear interpolation of azimuths and dips, respectively.

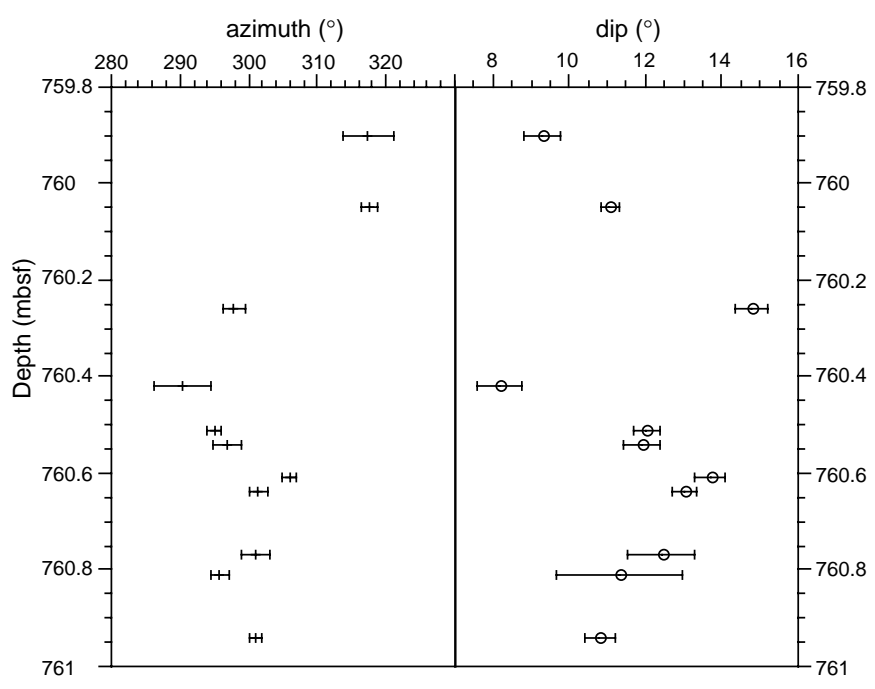

Figure 7. Average and standard deviation of dip and azimuth measurements in a set of 11 bedding planes, Hole 959D, 759.8-761 mbsf.

As in Hole 959D, almost all bedding measurements can be related to progressive rotations. Those rotations have many similar features in the two holes, including the same thickness (centimeter to decimeter scale) for the sets that define rotation axes, both increasing and decreasing downhole dips observed, and the same sudden changes in rotation axes orientation. However, in Hole 960C, the change in orientation of the rotation axes can often be followed between several successive sets. The vertical scale for these types of changes in orientation seems to be $2-5 \mathrm{~m}$, but the strong difference between the two holes is the strike of the rotation axes (Fig. 14). In Hole 960C, only two directions appear, $85^{\circ}$ and $125^{\circ} \mathrm{N}$, close to the strike of faults but clearly different from the main strikes of rotation axes in Hole 959D.

\section{DISCUSSION \\ Origin of the Progressive Tilts}

Two main mechanisms can be involved in the tilting of sedimentary beds at a centimeter to decimeter scale: tectonically induced rotation and wedge shaped sedimentation. An example of tilting induced by a normal fault can be seen in Sample 159-960C-26X-2, 117-124 cm (Mascle, Lohmann, Clift, et al., 1996). The apparent rotation (measured on core section) of these siltstones is $4^{\circ}$, with an increase of dip downhole. Either a progressive tilting or a rollover against an active normal fault can also be induced at another scale from the increase of average dip from 754 to $800 \mathrm{mbsf}$ in Hole 959D (see above and Fig. 11). On cores, many normal faults and tension veins were observed in the logged intervals; on FMS data, the strikes of faults and rotation axis appear to be strictly correlated. Many rotations are probably induced by progressive tilting against the normal faults.

However, this mechanism does not explain alternative rotation ways (decreasing and increasing downhole), especially at a centimeter scale. This alternative small-scale tilting can be explained by the 
Azimuthal image $\left({ }^{\circ}\right)$ and planar traces

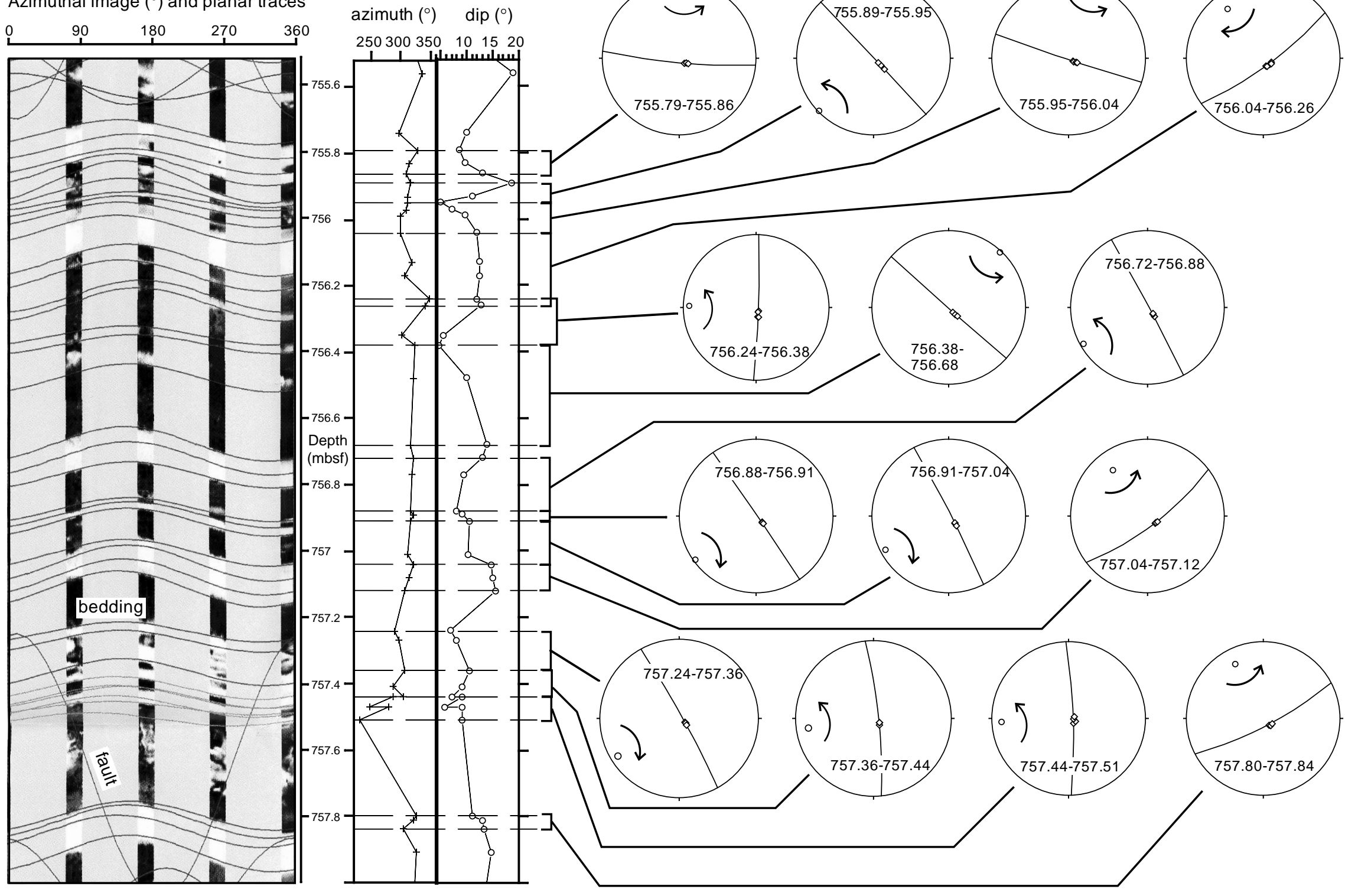

Figure 8. Interpreted FMS image (Hole 959D, 755.52-758 mbsf) and azimuth and dip of every sedimentary bedding plotted on the azimuthal FMS image. The Wulff nets (lower hemisphere) indicate the progressive rotations deduced from those measurements. Open squares $=$ the poles of bedding, open circles $=$ the rotation axes (pole of the great circle plotted), and arrows $=$ the direction of the rotation. 


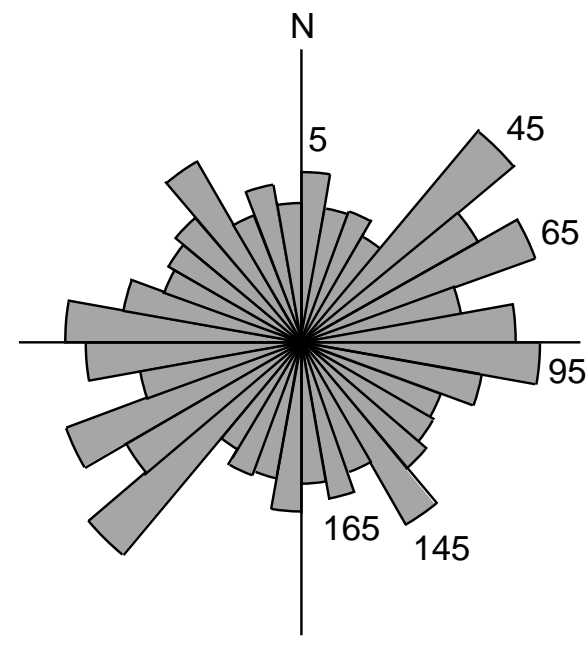

Figure 9. Rose histogram of rotation axes deduced from bedding measurements in Hole 959D (597 values, maximum 49 values).

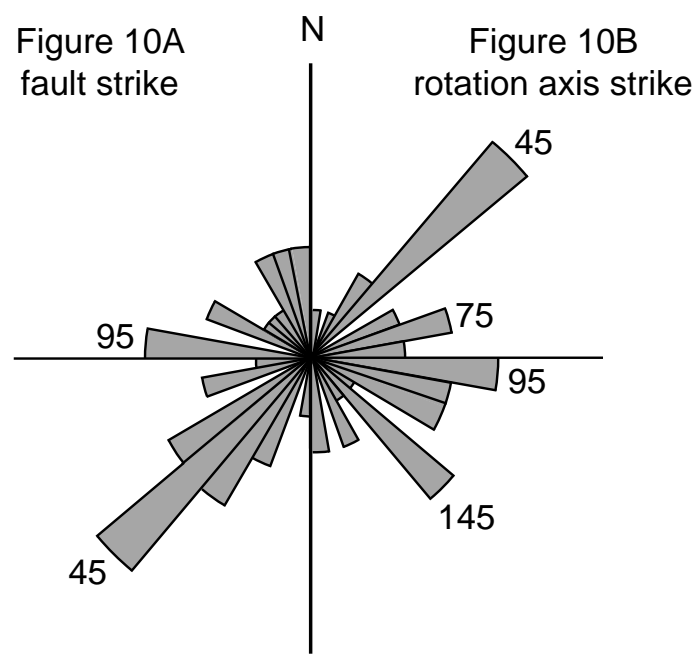

Figure 10. A. Rose histogram of fault strike in the interval $855-885 \mathrm{mbsf}$, Hole 959C ( 31 values, maximum 5 values). B. Rose histogram of rotation axes strike in the same interval ( 37 values, maximum 6 values).

rotation of sedimentary bedding in low-angle shear zones. As most of the faults observed on cores are growth faults, they appeared during sedimentation or diagenesis, were active at a time when the sediment was water rich, and were able to deform in a more or less ductile way. In such material, a restricted sliding on low-angle normal shear zones should produce a limited tilt increasing from the borders of the shear zone toward its center (increasing dip downhole, then decreasing).

Sedimentary structures can also explain sharp changes in dip, especially in the limestones logged in Hole 960C. A few angular relationships related to erosional surfaces at the base of grain flows can be seen in cores (e.g., Sample 159-960C-26X-2, 70-82 cm), where the apparent angle measured on core section reaches $2^{\circ}$ (Mascle, Lohmann, Clift, et al., 1996). But the most significant angles are found in cross-laminated coarse sediments. In Sample 159-960C$26 \mathrm{X}-1,126-130 \mathrm{~cm}$, the apparent dip of bedding increases downhole by $16^{\circ}$, then decreases by $14^{\circ}$ (Mascle, Lohmann, Clift, et al., 1996). Many cross-bedding structures can be observed on FMS images. They are involved in most of the rotation axes trending east-west to

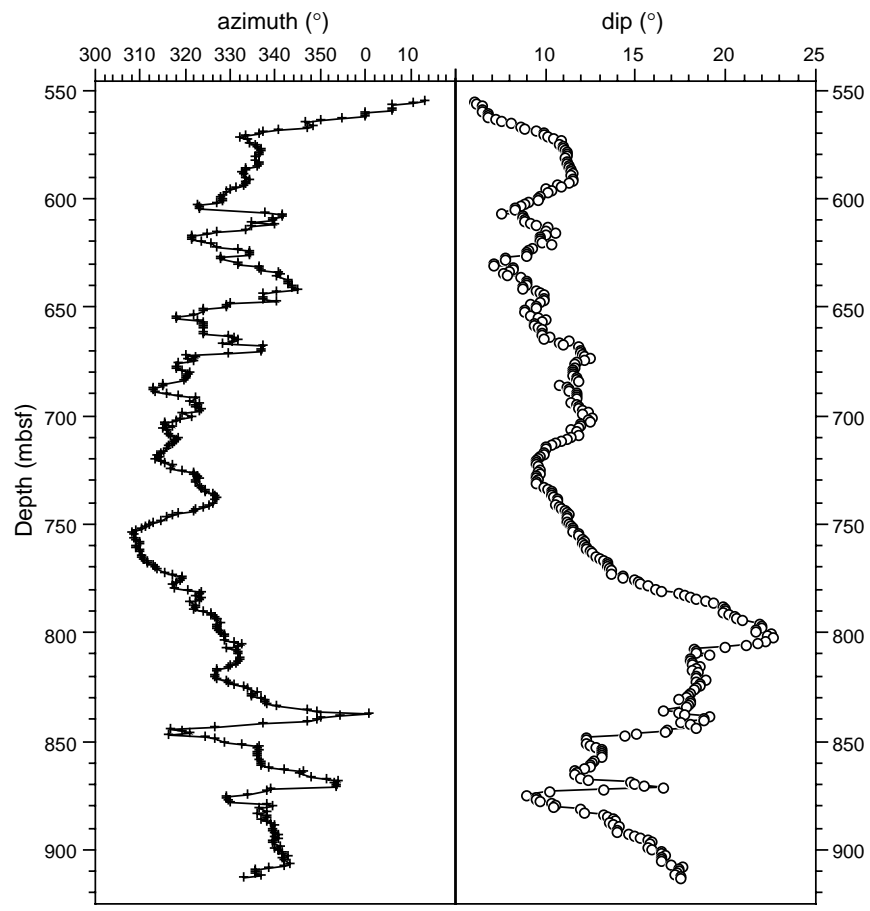

Figure 11. Azimuth and dip of sedimentary beds in Hole 959D. Each cross or circle is the average of all azimuth or dip measurements in an interval of 20 $\mathrm{m}$ around the point.

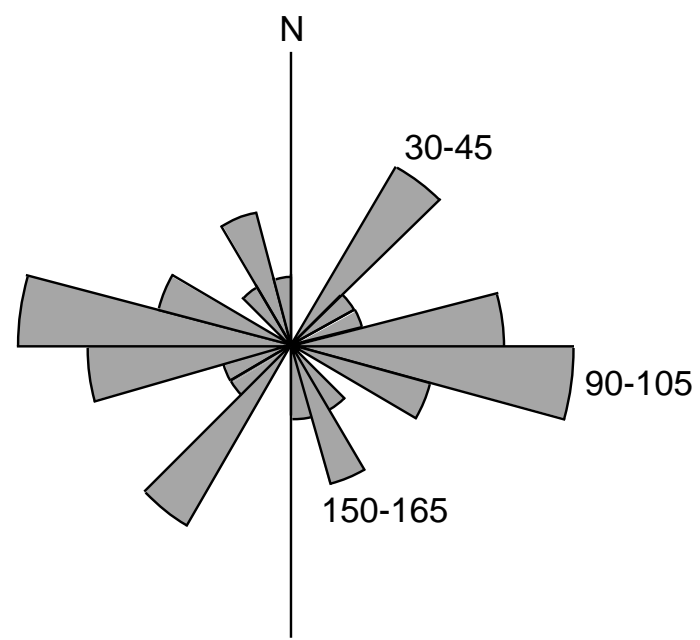

Figure 12. Rotation axes deduced from the dip and azimuth measurements smoothed on a 20-m interval, Hole 959D (18 values, maximum 4 values).

northwest-southeast, indicating a local slope and sediment transport direction north-northeast. The succession of wedge-shaped bedding probably results from a combination of several processes. Sedimentary processes related to grain-flow deposition of grainstones and packstones can explain the abrupt changes of the dips. Divergence of grain flows in a submarine fan can also explain the dispersion of the trends of the rotation axes.

However, these sedimentary processes can hardly be involved in the tilting of in situ deposited pelagic or hemipelagic sediments, as in Hole 959D. For this type of sediment, rotations are most likely related to faulting, either induced by regional tectonic stress or caused by gravitational sliding. However, in Hole 959D, sedimentary structures 
Figure 13. Azimuth and dip of sedimentary beds in Hole 960C. Top: each measured bed is plotted in a depth vs. azimuth and dip diagram. Bottom: a rose histogram gives the strike of the 13 faults measured in the same interval (maximum 4 values).

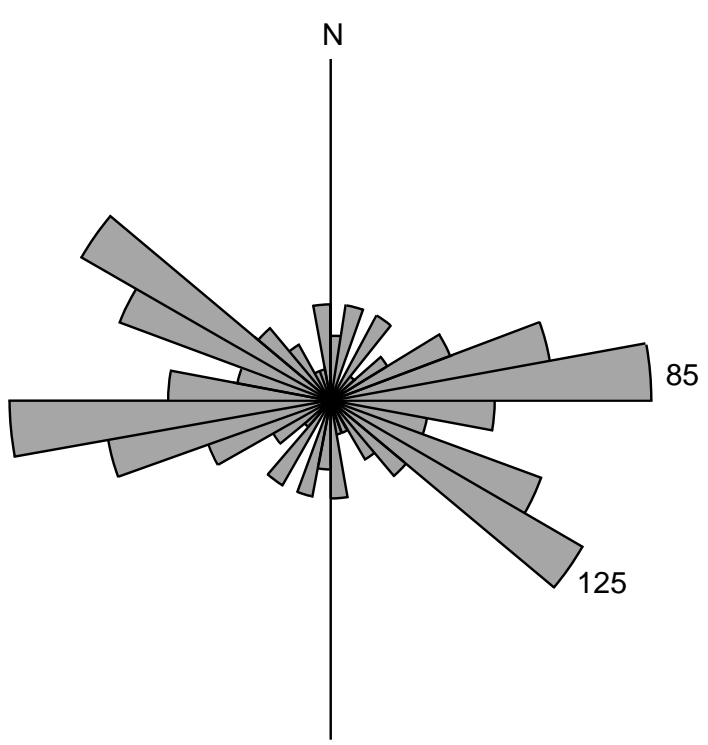

Figure 14. Rose histogram of rotation axes deduced from bedding measurements in Hole 960C (66 values, maximum 10 values).

can locally induce rotation axis. For example, a debris flow has been reported in the biosiliceous unit, age-correlative to slumped beds at Site 960 (Mascle, Lohmann, Clift, et al., 1996). Slumps were also noticed around 710 mbsf (Mascle, Lohmann, Clift, et al., 1996).

Some of the mechanisms invoked above are restricted to small scales. As progressive rotations have been observed at different scales, only tectonic mechanisms, and especially progressive tilting
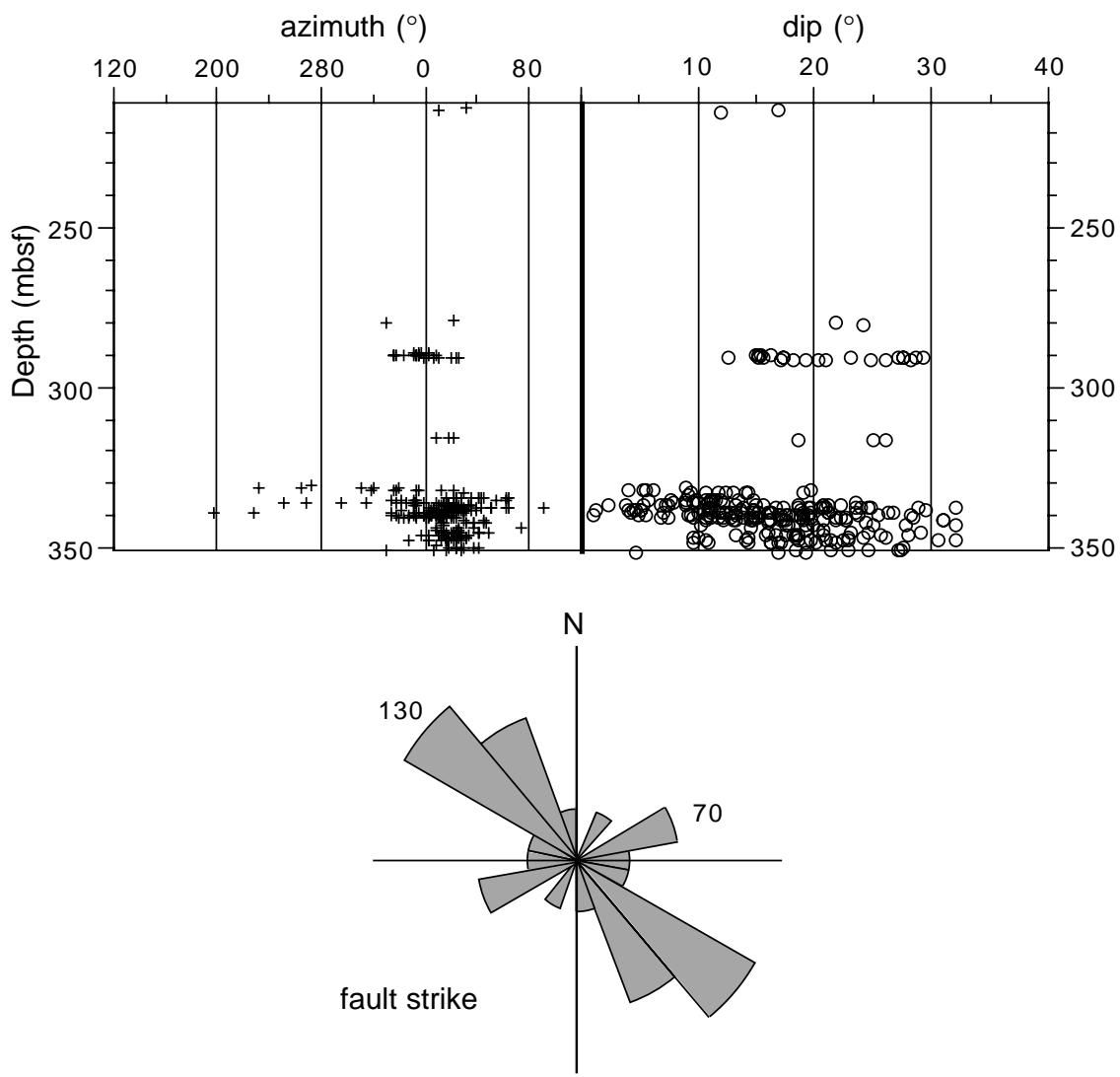

or rollover against normal faults, can explain the rotations occurring at larger scales (Fig. 11). The large-scale fault zones are probably located on lithologic interfaces. For example, the most striking example of tilting between 754 and 800 mbsf is related to the change between lithostratigraphic Units II (porcellanite) and III (claystones). More localized changes in lithology (changes in carbonate or clay contents) or discontinuities can also localize the dip-slip deformation and associated tilting.

\section{Faults and Rotation Axes Strike}

The tectonic setting of the logged interval is different in Holes 959D and 960C. In Hole 959D, the studied interval is clearly post-tectonic. The only tectonic activity expected in this interval is gravitydriven. In Hole 960D, the studied interval is contemporaneous with the tectonic activity of the continent-ocean transform fault. However, those sediments are poorly deformed. Therefore, two main interpretations can explain the fault strikes: either the faults are related to gravitational processes, and the fault strike is perpendicular to the slope, or the faults are related to regional stresses, and the fault strike depends on the orientation of the principal stresses.

In Hole 960C, fault striking shows two sets of faults (striking $70^{\circ} \mathrm{N}$ and $130^{\circ} \mathrm{N}$ ) separated by $60^{\circ}$ (Fig. 13). Assuming those two sets to be conjugated, the orientation of principal horizontal stresses $\sigma_{\max }$ and $\sigma_{\min }$ are $100^{\circ}$ and $10^{\circ} \mathrm{N}$, respectively. This orientation is exactly the expected orientation of stresses in the vicinity of a rightlateral strike-slip fault striking $55^{\circ} \mathrm{N}$, which is parallel to the transform margin. So we suggest that the Coniacian-Santonian limestones of Hole 960C recorded the stress field induced by the active transform located southward at that time. However, the occurrences of grain flows show that a topographic slope existed also at the time, and some faulting (especially trending $130^{\circ} \mathrm{N}$ ) may have been produced by gravitational sliding. 
In Hole 959D, the principal directions of fault or rotation axis are numerous $\left(40^{\circ}, 65^{\circ}, 95^{\circ}, 145^{\circ}\right.$, and $\left.165^{\circ} \mathrm{N}\right)$, and a simple interpretation as conjugated faults is not obvious. The fault and rotation axes can also be interpreted as reworking of older directions: Lower Cretaceous strike-slip faults striking $95^{\circ} \mathrm{N}$ have been identified along the northern border of the Marginal Ridge, and synrift north-south dipslip faults are known in the Ivorian Basin as faults striking $45^{\circ} \mathrm{N}$ (Basile et al., 1992, 1993). $65^{\circ}$ and $165^{\circ} \mathrm{N}$ are the directions of the Marginal Ridge and of the Ivorian Basin, respectively. Those two directions can represent the strike of the rotation axes associated with the thermal subsidence of the Marginal Ridge and Ivorian Basin, respectively. It was noted that the $40^{\circ}$ and $95^{\circ} \mathrm{N}$ directions can define a conjugated fault set induced by stresses $\sigma_{\max }$ and $\sigma_{\min }$ striking eastnortheast to west-southwest $\left(70^{\circ} \mathrm{N}\right)$ and north-northwest to southsoutheast $\left(160^{\circ} \mathrm{N}\right)$, such as the present-day stress field defined from Hole 959D deviation and breakout orientations (Mascle, Lohmann, Clift, et al., 1996).

\section{CONCLUSIONS}

This study shows that the northern slope of the Côte d'IvoireGhana Marginal Ridge does not result from a simple tilt between the edge of the ridge and Ivorian Basin. The regional slope, which can be observed at the scale of the seismic lines, results from the interaction between several gravity-driven slidings, whose directions are controlled by the thermal subsidences of the transform and divergent margins, and probably by the orientations of older faults.

Finally, this study shows that the FMS logging tool can be used to determine very precisely the tilting history of a sedimentary sequence. This tool makes it possible to describe the subsidence not only as a depth vs. time curve but as a depth and tilting orientation vs. time. As 3-D seismic reflection and more generally 3-D data sets develop, FMS data will make the study of a $3-D$ subsidence possible.

\section{ACKNOWLEDGMENTS}

Thanks to JOIDES and Sedco officers and crew, to ODP technicians, and to R. Sammy (Schlumberger engineer), who were in charge of shipboard operations and data acquisition. Thanks to N. Kaul and J. Mascle for reviews that improved this paper. Special thanks to A. Pecher, who provided several versions of the software STEM dedicated to stereonet and statistical analysis of geological data. This work has been funded by INSU (ATP Géosciences marines).

\section{REFERENCES}

Basile, C., Brun, J.P., and Mascle, J., 1992. Structure et formation de la marge transformante de Côte d'Ivoire-Ghana: apports de la sismique réflexion et de la modélisation analogique. Bull. Soc. Geol. Fr., 163:207216.

Basile, C., Mascle, J., Popoff, M., Bouillin, J.P., and Mascle, G., 1993. The Côte d'Ivoire-Ghana transform margin: a marginal ridge structure deduced from seismic data. Tectonophysics, 222:1-19.

Basile, C., Mascle, J., Sage, F., Lamarche, G., and Pontoise, B., 1996. Precruise and site surveys: a synthesis of marine geological and geophysical data on the Côte d'Ivoire-Ghana Transform Margin. In Mascle, J., Lohmann, G.P., Clift, P.D., et al., Proc. ODP, Init. Repts., 159: College Station, TX (Ocean Drilling Program), 47-60.

Gorini, M., 1977. The tectonic fabric of the Equatorial Atlantic and adjoining continental margins [Ph.D. thesis]. Columbia Univ.

Mascle, J., and Blarez, E., 1987. Evidence for transform margin evolution from the Côte d'Ivoire-Ghana continental margin. Nature, 326:378-381.

Mascle, J., Lohmann, G.P., Clift, P.D., et al., 1996. Proc. ODP, Init. Repts., 159: College Station, TX (Ocean Drilling Program).

Sage, F., Pontoise, B., Mascle, J., Basile, C., and Arnould, L., 1997. Crustal structure and ocean-continent transition at marginal ridge: the Cote d'Ivoire-Ghana marginal ridge. Geo-Mar. Lett., 17:40-48.

Serra, O., 1989. Formation MicroScanner Image Interpretation: Houston (Schlumberger Educ. Services), SMP-7028.

Date of initial receipt: 19 September, 1996

Date of acceptance: 7 May 1997

Ms 159SR-005 